\title{
Hereditary central diabetes insipidus
}

INSERM

\section{Source}

INSERM. (1999). Orphanet: an online rare disease and orphan drug data base. Hereditary central diabetes insipidus. ORPHA:30925

Hereditary central diabetes insipidus is a rare genetic subtype of central diabetes insipidus (CDI, see this term) characterized by polyuria and polydipsia due to a deficiency in vasopressin (AVP) synthesis. 